\title{
Old Believers in the Territory of the Russian Empire*
}

\author{
GERD STRICKER
}

\section{From Schism to Revolution}

The Old Believer schism was the most significant split in the history of the Russian Orthodox Church. We are aware of earlier, minor, breakaway movements such as the cloth shearers (strigolniki) in 14th century Novgorod and Pskov or the Judaisers in Novgorod and Moscow a century later. Of course many important sects developed as protest movements from within Russian Orthodoxy, mainly from the 18th century onwards (e.g. the Khlysty who led to the Skoptsy; the Dukhobors who led to the Molokans through to the Tolstoyans in the 20th century, and many others besides). Seen in the long term however, none of these gained importance or persisted to the same extent as the Old Believer movement, which in spite of countless schisms remains to this day a force to be reckoned with by the Moscow Patriarchate. The efforts of the patriarchate since 1971 to establish good relations with the Old Believers speak for themselves.

Unlike other divisions within Orthodoxy, the roots of the Old Believer movement lay not in a protest against the doctrine or life of the Orthodox Church, but rather in a rejection of formal innovations in ${ }^{3}$ rites, church practice and written tradition, which seem unimportant today. In the 17 th century the borders of the Russian Empire were extended to the south west (e.g. by the subjection of eastern Ukraine to Moscow in 1663). This development, which had in fact begun decades earlier, strengthened church links with Constantinople and resulted in a reconsideration of the Greek roots of Russian Orthodoxy. It had already been noted in Russian church circles that the centuries of isolation following Tatar rule (1240 to approximately 1440) had led to a considerable alienation from the Greek mother

*This article draws heavily on research undertaken by my longstanding teacher, Professor Dr Peter Hauptmann, Director of the Ostkirchen-Institut of the Evangelical Theological Faculty at the University of Münster, Westphalia. Over many years he has repeatedly turned his attention to the Old Believers. I would like to thank Rev. Raymond Oppenheim for his helpful suggestions, statistical data and corrections. 
church. This alienation found visible expression in the declaration of autocephaly by the Moscow metropolitanate in 1448 - a direct reaction to the Council of Ferrara-Florence (1438/1442) when Constantinople subjected itself to the Pope in Rome in order to receive military aid against the Turkish conquest - and in Moscow's elevation to a patriarchate in 1589 . Of course there had been mistakes in translating the holy texts from the very beginning and over the centuries errors slipped in, for the most part simply from repeated transcribing of the holy books, liturgical works and writings of the church fathers, which often gave a false interpretation of the texts.

Increasing church contacts with Constantinople and improved knowledge of Greek revealed that liturgical practice in the two churches had gone different ways in the course of a half millennium. This development was naturally prejudiced by the fact that in Kievan Rus' it was not Greek but Slavonic that was the language of the church - in today's terminology, Old Church Slavonic. In the late 1740s moderate reforms were commenced, particularly encouraged by Tsar Aleksei Mikhailovich. The way for reforms within the church had been prepared by the Zemski sobor of 1648-49 and the ulozheniye of 1649.

When Metropolitan Nikon (1605-81) became patriarch in 1652 he forced through the reforms in an extremely inept way. With no regard for church members or traditions, he imposed reforms at the 1653-54 council which were supposed to 'correct' church customs and religious texts. The innovations in the sacred books provoked the opposition of a large section of the priesthood, whilst the changes in church customs for the most part unsettled large sections of the faithful: should they, for example, sing Alleluia three times at certain points in the liturgy, instead of the usual two; was the substitution of bows for many prostrations pleasing to God and would it have the same effect as the countless former prostrations? A further point at issue was whether the name Jesus should be written with one I (ISUS), as before, or with two (IISUS), the new version. The greatest indignation of all was caused by the inconsiderate imposition of the so-called three-fingered cross, that is, to cross oneself with three fingers (symbolising the Trinity) instead of as before with two fingers (symbolising the two natures of Christ: true man and true God). Every single Orthodox believer was affected by the new ruling over crossing oneself, and so the defence of the two-fingered cross became the unequivocal symbol of the old faith (hence Old Believers - Starovertsy) and the old rites (hence Old Ritualists - Staroobryadtsy) and a symbol of opposition to and protest against the reforms as a whole.

Five instead of the previous seven prosphora (altar bread in the form of leavened cakes, $E d$.) were to be used at the proskomide 
(preparation of the bread and wine for the Eucharist, Ed.); moreover, the seal imprinted on the prosphora was changed. The seal was originally round or rectangular and encircling the cross in the centre were the words: 'Behold the Lamb of God who bears the sins of the world' (se agnets Bozhij vzemljaj grekh mira), John 1:29. The new seal is square and around the cross are the letters IC XC HI KA, meaning 'Jesus Christ is victorious'. The route previously taken by the processions on Holy Saturday was changed to run from west to east rather than from east to west. In the Nicene creed the epithet 'true' ('istinny') in front of 'Lord, the Holy Spirit, the Giver of Life' was removed, and in the following phrase the present tense was replaced by the future: 'whose kingdom will have no end'.

Important changes were also made in church singing. The fact that Old Believers preferred one voice (yedinoglasiye) and the Orthodox many voices (mnogoglasiye) was not the decisive point - Nikon wanted just one voice, but did not have much success. 'Sweet song' ('sladostnoye peniye') prevailed from Kiev to Moscow. More significant was the difference between the Old Believers and the Orthodox in so-called khomony (khomovoi raspev): over the centuries it had become usual in church chant to give the silent, i.e. unspoken, semi-vowels full value, which meant that texts spoken or sung in this way were often incomprehensible. Nikon also decreed a reform in this field which aimed at the spoken language becoming the basis for chant (istinorechiye). This innovation, too, was rejected by the Old Believers with varying degrees of vehemence from group to group.

It has already been stated that the general anger at these reforms of ritual cannot be explained without a reference to the widespread feeling that the end of the world was nigh, a feeling which enabled people who opposed the Nikonian reforms to explain them as a sign of the approaching end of the world, the Last Judgement, and of the Antichrist, who had already appeared in the person of Nikon. By referring to Revelation 13 and 15, where the end of the world is linked to the number 666 , and with further combinations, various texts The Book of Faith (Kniga o vere) and Kirill's Book (Kirillova kniga) - had calculated the year 1666 to be the year of the coming of the Antichrist, personified in Patriarch Nikon, and later in Peter I and others, with the state as the Kingdom of the Antichrist. These interpretations became a bbasic component of the Old Believers' eschatological ideas, though their positions varied, with the priestless Old Believers amongst the most radical. Georgi Florovsky formulates this state of affairs as follows: "It is not the "rite" but the "Antichrist" which is the theme and secret of the Russian schism."

'Georgi Florovsky, Puti russkogo bogosloviya (Paris, 1937), p. 67. 
Archpriest Avvakum, although not the only one, was by far the most important spokesman for the traditionalists who did not want to diverge in the slightest from the old customs. After a lengthy trial he was sentenced to death at the stake in 1682 .

His death sentence was not an exception, but rather characteristic of the way in which the state, in cooperation with the church, proceeded against the protestors. The state's action against the Old Believers was legitimised by a decree ( $u k a z)$ in 1683 which placed Old Believers outside society by discriminating against them as enemies of the state. Their only hope of escaping persecution was to flee into-hiding. Vast numbers followed their leaders into inhospitable areas of the empire - into the Trans-Volga region, which was then hardly inhabited (the present day areas around Saratov and Gorky), where the Kerzhenets and Irgiz monasteries acquired fame; - towards the Pomore region in Karelia on the White Sea, where the famous monasteries on the River Vyg were established in the last quarter of the 17 th century. The industrialisation of the Ural mountains brought thousands of Old Believers to settle there; the owners of mines and iron foundries often were Old Believers, and it is clear that they engaged only fellow believers in their enterprises. The vastness of Siberia always offered a place of refuge, as did the Caucasus. The Don region was also especially popular, where runaway serfs and other fugitives already formed an adventurous but strictly organised society - the Cossacks. The number of Old Believers in this area increased to such an extent that the terms 'Old Believers' and 'Cossacks' became more or less synonymous. Early on the Old Ritualists, as Old Believers are more aptly called in Russian, crossed the Russian borders and fled — first to the Baltic region in the north and to the Starodub and Vetka monastic centres near Gomel' in the west on what was then Polish territory; then in the 18th century they travelled further afield - to Austro-Hungary, to Poland, to Bukovina and the Danube delta, to Turkey, to Mongolia, later to America and Australia. After the annexation of large areas of Poland by the Russian Empire many Old Believers in the districts of Suwalki and Sejny migrated into German East Prussia - the remnants of these Old Believers can still be found in Wojnowo in present day Poland.

It was in their search for freedom, for the legendary 'land of the white water', where the Antichrist does not reign, that whole groups of Old Believers headed towards Asia in the 18th century; many others, however, went involuntarily, exiled there by the tsarist administration. In the Altai mountains - in the valleys of the Rivers Uba and Bukhtarma - there are still tens of thousands of Old Believers, whose predecessors were deported here in 1764 from Vetka and Starodub, the centres of Old Belief. Despite the poor land, they 
devote themselves to agriculture. The so-called Aral'tsi are Old Believers in today's autonomous regions of the Kara-Kalpak SSR on the Aral Sea. They have settled in the deltas of the Syr-Darya and Amur-Darya as well as on the islands of the Aral Sea, where they make a living by fishing. (How their way of life is developing, now that the Aral Sea is drying up, needs investigation.) In 1875 their predecessors were expelled from the Union of Ural Cossacks because of their beliefs and were settled in Central Asia. Both groups - i.e. those in the Altai Mountains and those on the Aral Sea - have attracted the interest of ethnographers during the Soviet period. The way they have preserved their belief, traditions and customs because of their geographical isolation has aroused widespread astonishment (cf. the report of the expedition by the Academy of Sciences of the USSR: Bukhtarminskiye staroobryadtsy. Materiali kommissi ekspeditsionnykh issledovani. Vyp. 17, Leningrad 1930 - The Old Believers of Bukhtarma. Documents by the Commission for Research Expeditions. Vol. 17). There are still reports about Old Believers groups and families - who are being discovered in Far Siberia and Asia.

The Old Believers settled together in their places of refuge, hoping that they would be able to live undisturbed according to their beliefs. However, even into the early years of the 18th century Old Believer settlements were conquered again and again by the Russian army and the believers forced to return to the state church. Many of them would set fire to their villages as the soldiers approached and burn themselves and their families to death. In particular the so-called Filippovtsy, a very radical group, saw death by fire as the only means of escaping the state, ruled by Satan, and the church, ruled by the Antichrist. Under Peter the Great the physical persecution for the most part ceased, but economic and other pressures (double taxation) remained and the exodus continued.

In the 18th century the migration of Old Believers to the traditional places of refuge did not stop (often they were accompanied by deserters, escaped prisoners and others). ${ }^{2}$ Within the rural population which often opposed the Nikonian reforms the Old Believers found much sympathy. As George Vernadsky notes:

The danger of the situation for the government's stability lay not so much in the theology of the Old Believers, as in the sympathy and support that the Old Believer movement was gaining from large sections of the population, whose motives were not merely religious but social and political as well. Though religious in its

${ }^{2}$ Viktoria Pleyer, Das russische Altgläubigentum. Geschichte, Darstellung in der Literatur (Munich, 1961), p. 43. 
origin and its essence, the Old Believers' opposition to authority was potentially the nucleus of a widespread revolutionary movement. $^{3}$

In every area of Russia there were Old Believer settlements and colonies. Consequently considerable differences arose between the various groups. By the mid-18th century we can perceive significant groups who were approaching the state again and - like the state church - interceding for the tsar in the liturgy. Efforts by Old Believers who remained faithful to the priesthood to achieve recognition by the state church met with partial success in 1799-1800: they were permitted to return to the state church but retain their own rites. This union between Old Believers and the state church was called yedinoveriye (common faith) and its adherents, Yedinovertsy. It was not only Old Believers faithful to the priesthood who joined the official church, but surprisingly some from priestless groups too (see below). The success of this compromise was only moderate, even though a large number of so-called 'Old Believer missionaries' priests from the Orthodox church who had been especially trained to win back Old Believers - stepped into action. Yedinoveriye never became a real counterbalance to the Old Believer movement. The state church's concession came at least 100 years too late, and even then it was only half-hearted - the Yedinovertsy were not permitted to have a bishop of their own, and Orthodox believers were forbidden to communicate with them. Yedinoveriye was probably seen by the state church as no more than a roundabout way of getting Old Believers finally to return to its fold.

The plague of 1771 raised the profile of Moscow's Old Believers: they were allowed to found hospitals and cemeteries as well as churches, monasteries and other buildings. Thus the groups which were most important at that time acquired the centres which they in part still possess today: for those faithful to the priesthood, the Rogozhsky Cemetery; for the priestless Fedoseyevtsy, the Preobrazhensky Cemetery; and for the priestless Pomortsy and radical Filippovtsy, places which are no longer at their disposal. The authorities and state church were not a little surprised to find that at the end of the building phase the 'cemetery chapels' that had been envisaged when the concessions were granted had become the largest cathedrals of Moscow, with space for 10,000 - in particular the Pokrov Cathedral at the Rogozhsky Cemetery.

The 19th century was characterised by a constant swing from persecution to toleration. Alexander I continued the policy of

${ }^{3}$ George Vernadsky, The Tsardom of Moscow (New Haven/London, 1949), Vol. 5 Part 2, p. 696 . 
toleration which Catherine II had introduced. New settlements of Old Believers were established, monasteries and communities were founded, and countless churches and chapels built. Under Nicholas I (1825-55) there followed a sudden change. All conceivable measures were taken to quash the raskol. First and foremost measures were taken against priests to strike a severe blow to the vast majority of Old Believers who remained faithful to the priesthood; then instructions were issued to close all Old Believer institutions: monasteries, churches, hospices, etc. were sealed up, (mainly in the years 1848-55), including the Moscow cathedrals of the Rogozhsky and Preobrazhensky cemeteries and the monasteries on the Vyg, Irgiz, and Kerzhenets. It was an attempt to destroy systematically the Old Believer movement, but it was only the institutions that were affected, not Old Belief as such. Alexander II (1855-81) revoked some of his father's legislative and administrative measures, but these changes were not carried out in practice. During the reign of Alexander III (1881-94) Konstantin Pobedonostsev, Over Procurator of the Holy Synod, in effect the Minister for Religious Affairs, attempted to banish the Old Believers to the boundaries of the empire again. The new laws of 1883 thus led to a worsening of the situation for Old Believers, though compared to the measures of Nicholas I they in fact represented an alleviation. The Old Believers now received some civic rights, and churches that had been closed 25 years earlier were 'unsealed' (but neither the monasteries nor the Moscow centres - the Moscow churches were not unsealed until 1905!). The revolution of 1905 and the Edict of Toleration proclaimed in its wake provided opportunities for growth, but the First World War prevented the success of this development.

After the 1917 Revolution Old Believers moved more into the background, but they did not disappear. It can even be said that relatively speaking - they were far less affected than the patriarchal church by succesive waves of religious persecution. It is difficult to give statistics - even the various groups living in diaspora have no overall picture themselves. Peter Hauptmann gives a cautious estimate of between three and 12 million in the USSR. ${ }^{4}$ But it has to be stressed that the Old Believers actively participating in officially registered old-rite congregations will not exceed half a million - if we see the gap between these numbers we realise that the question 'How many Old Believers lived in the Russian Empire?' remains unanswered - as in 1904, when a specialist on Old Believers, A. S. Prugavin, stated: 'Two million or 20 million - who knows?'

${ }^{4}$ Peter Hauptmann, 'Das russische Altgläubigentum 300 Jahre nach dem Tode des Protopopen Avvakum' in Kirche im Osten, No. XXIX (1986), p. 71.

${ }^{5}$ A. S. Prugavin, Staroobryadchestvo vo $20 y$ polovine $X I X$ v. (Moscow, 1904), pp. 5 and 7 . 


\section{The Old Believer Movement and the Question of Priesthood}

The fact that no bishop joined those who disagreed with the reforms was to determine their fate. Bishop Pavel of Kolomna, the only one at the council of 1653-54 to add a written reservation to his signature on the reforming synod's decisions, was burnt at the stake in 1656 , for this very reason according to Old Believers. He was the only bishop to sympathise openly with the opponents of the reforms. In Orthodoxy priests cannot be consecrated without a bishop, and so after the death of all the priests who had been consecrated according to the old rites, the opponents of reform - the Old Believers - should consequently have had to manage without priests. A considerable number of Old Believers did in fact take this difficult path, although it should be pointed out that in most Old Believer groups without a priesthood, a new leadership position (nastoyatel' or nastavnik) developed over the last two centuries, creating a different type of priestly office.

\section{Old Believers without a Priesthood}

The first things to disappear were the sacraments administered by priests, the loss of the sacrament of marriage being the most significant, because the priestless Old Believer groups, which were from the outset prone to further divisions, separatèd over this issue. Baptism and confession were not a problem - but the liturgy had to go. Who should lead it? Of the more than 25 priestless Old Believer denominations in existence 150 years ago, two main groups are prominent today. In the case of the Pomortsy - the most significant group without priests, embracing almost three-quarters of the priestless believers - the nastavnik (teacher/church leader) has the right together with the parents of the engaged couple to perform marriages. The Fedoseyevtsy reject marriage on principle, but this necessitates them begetting their children 'in sin'. However:

If the majority of the Fedoseyevtsy adhere to the original view of all Bezpopovtsy [priestless Old Believers] that there can be no more marriages following the apocalyptic extinction of the Old Orthodox priesthood and thus strictly speaking all Christians are pledged to celibacy, at the same time the traditional church penalties for unmarried couples living together after the birth of children are light, and thus family and church life in both groups [Pomortsy and Fedoseyevtsy] is not all that different. ${ }^{6}$

${ }^{6}$ Peter Hauptmann, 'Das Gemeindeleiteramt bei den priesterlosen Altgläubigen' in Fairy von Lilienfeld, Unser ganzes Leben Christus unserem Gott überantworten (Göttingen, 1982), p. 479. 
A considerable number of Fedoseyevtsy appear today to be joining the aforementioned Pomortsy. The Filippovtsy, a group of priestless Old Believers that is insignificant now, advocate total sexual abstinence, so their continued existence depends on winning over outsiders, which has been especially difficult since the 1917 Revolution.

The priestless Old Believers have the term pomore (coastland) in their official or unofficial names (Pomortsy: Staroobryadcheskaya Pomorskaya Tserkov' - Old Rite Church of the Pomore; Fedoseyevtsy: Starobryadtsy or Staropomortsy - Old Rite Old Pomortsy). Even the Moscow church, which is certainly far enough from the White Sea, bears the title Moskovskaya Pomorskaya starobryadcheskaya obshchina. The Pomore region stretched from the north Russian region of Karelia to the northern Urals but was mainly centred on the coastal area of the White Sea. The monasteries along the River Vyg in Karelia were especially important for the priestless Old Believers, whilst the Solovetski monastery on a White Sea island, destroyed by state troops in 1676 after an eight-year siege, became a symbol for all Old Believers.

It was not merely by chance that the first and most significant centres of the priestless Old Believers arose in Karelia: there had seldom been any priests in these remote regions - nobody wanted to serve here, and there were not even any churches in these scattered villages consisting of only a few houses. The people were used to managing without priests - a monk, a hermit, someone from the village assumed the role of spiritual leader in a small community. Thus it is hardly surprising that the strongest bastions of the priestless Old Believer movement were found in the Pomore region.

It was not only because of the Pomore coastal region that priestless Old Believers clung to this geographical notion; much more important were the so-called Pomorskiye otvety (Answers from the Pomore), which to this day form the theological basis of the priestless Old Believer movement. In about 1725 Andrei Denisov replied on behalf of the Old Believers to 106 questions directed to them by Neofit, an Orthodox monk, who was acting on behalf of the Holy Synod. The state church found it was not in a position to give any reply to this profession of faith by the priestless Old Believers. Thus the root pomor evident above all in the name of the main group, the Pomortsy, is probably a reference to the Pomorskiye otvety and the Pomorskoye soglasiye (Agreement of the Pomore) to which the Pomorskaya community knew it was committed. The present-day centres of the priestless Old Believers movement can be found, as before, in the former places of refuge - above all in the Baltic republics, especially Lithuania (Vilnius) and Latvia (Riga), but also in Moscow. 
The rejection of the priesthood led not only to the ending of the sacrament of marriage, but also to other important changes: with no priests or deacons totally new forms of service were needed and in the church building there was no longer any need for the altar room to which only the priest had access - the wall of icons without the Royal Doors now forms the east wall of the church.

\section{Old Believers Loyal to the Priesthood}

In comparison to the smaller number of Old Believers who reject the traditional priesthood, the Old Believer denominations that remained faithful to the priesthood seem numerically more significant. They acted less consistently than the priestless Old Believers over the decisive issue of priesthood (and over other issues too), and so they retained a greater proximity to the state church. They did not split up into competing groups as often as the priestless Old Believers, and so to this day they form a much more united body. As time passed, the priests who had been ordained according to the old rites died out and the problem of their successors came into sharp focus. Various approaches were adopted. Many groups enticed priests away from the patriarchal church and recognised them as valid priests after a simple ritual of repentance and purification (isprava) when they renounced the state church: the 'runaway priests' were tempted to join the Old Believers by high stipends and also the high ethical standards of these communities. One of the names for the Old Believers who remained loyal to the priesthood was derived from these priests who deserted the Orthodox church: Beglopopovshchina and Beglopopovtsy (those with the runaway priests). Some of the deserting priests turned out to be imposters. Other groups rejected this method of maintaining a priestly ọffice and acted in a similar way to the priestless Old Believers, managing with a provisional administrator and leader, known as the ustavchik (literally 'rubricist'). In time this office assumed many of the characteristics of the priesthood.

In 1847 an Old Believer hierarchy was founded in Belaya Krinitsa in Bukovina (in what was then Austro-Hungary and is now Romania). The Greek Bishop Ambrosios of Sarajevo (Bosnia) had received an interdict at the instigation of the Turkish government and had fled from the area under Turkish sovereignty. He was won over to the Old Believer movement and consecrated two bishops, who in turn consecrated another ten bishops. Some of them travelled secretly to Russia where they established an Old Believer hierarchy. The hierarchy was not, however, recognised by all groups loyal to the priesthood because of considerable doubts about its canonicity. 
Although this Old Believer hierarchy embraces nowadays perhaps half of the total Russian Old Believer movement worldwide, it is not possible to ignore the fact that a considerable proportion of Old Believers who remained loyal to the priesthood believed that they could not recognise the hierarchy established by Ambrosios. These continued to make do with priests won over to their cause and provisional leaders. The earlier nickname Beglopopovshchina (those with runaway priests) became associated above all with this group. Their main doubts of the Belaya Krinitsa hierarchy lay in the question of whether Ambrosios had really converted to the Ord Believer movement - for in 1849 after one year in Belaya Krinitsa he was told to leave by the Hapsburg government, after pressure from Nicholas I, and he moved to present-day Slovenia. Until 1859 he was paid a pension by the Old Believers. He died as a poor man in 1863 and was buried in Trieste.

Moreover, Metropolitan Ambrosios had carried out at least the first bishops' consecration in 1847 alone, without the assistance of another bishop, against Canon I of the Apostolic Canon, which requires the laying on of hands by two bishops to consecrate another bishop. Furthermore, at this time Ambrosios had already been suspended by the Patriarch of Constantinople - albeit under pressure from the Turkish government. Despite this, as mentioned above, a majority of Old Believers loyal to the priesthood acknowledged the authority of the Belaya Krinitsa hierarchy and the bishops they sent to Russia. These established their centre and the see of the "Archbishop of Moscow and All Russia' at the Moscow Rogozhsky Cemetery. This centre proceeded to assume the leading role which had previously been given to monasteries along the Kerzhenets, in Starodub and along the Irgiz. The vast majority of Old Believers loyal to the priesthood do not in fact reject the state and 'Nikon's Church' as absolutely as the priestless Old Believers - and it became gradually apparent that the differences between themselves and the priestless Old Believers were nearly as great as the differences between the state church and the priestless Old Believers. At any rate, the boundaries are fluid.

\section{The Cultural Achievements of Old Believers}

From a cultural point of view, the Old Believer monasteries formed important centres of literature and education, of tradition and theological debate. Collectively, their level of education was higher than that of the rest of the population of Russia and among the Old Believers it is the priestless groups that - to this very day - manifest a particularly high cultural level. The Vyg monasteries were the 
spiritual centres of the priestless Old Believer movement until their closure by the state in 1855 . Here Andrei and Semen Denisov wrote their creed, the famous Pomorskiye otvety (Answers of the Pomore); the believers collected old writings and icons (from the times before Nikon), taught their children to read and write, and owned printing presses though these were liable to be confiscated.

Although they were not of such a high standard as the priestless Old Believer monasteries on the River Vyg, the monasteries of Old Believers faithful to priests in Vetka and Starodub near Gomel' and on the Don, Kerzhenets and Irgiz - in which literature, icon-painting and church song were piously cultivated - were of great importance. Instructive and polemical writings originated in these monasteries which built up libraries and also had an underground press.

Old Believers were permitted to print their own material during Catherine II's reign, and their printing methods became widely used. This remained the case even when banned again after Catherine's death (1797). On the one hand pre-Nikonian religious literature was printed; on the other, polemical and apologetic treatises were disseminated. In addition, there were biographies and historical representations in which the stances of the Old Believers were defended. (A study of the cultural influence of the Old Believers on Russian history over the last 300 years would be of the greatest interest.)

\section{The Old Believer Movement after the Revolution}

The Russian Old Believer movement was greatly affected by the events of 1917. Old Believers were subjected to the same laws as other denominations - laws which restricted the life of the religious communities. However, two things should be borne in mind. Firstly, the religious persecution during the first decade of Soviet rule was aimed initially at the Russian Orthodox Church to which, at least nominally, the majority of Russians, Ukrainians and White Russians belonged, and which was seen as the 'stronghold of reaction' and 'last bastion of the tsarist regime'. As is well known, the Baptists, Adventists and Pentecostals enjoyed their greatest freedom ever as well as their greatest missionary successes to date in the 1920s. And as is equally well known, the Renovationist movement, a split within the Orthodox Church, was able to last only because it had the support of both party and state.

Secondly, the Old Believer movement as a whole made up only a small part of the ethnic Russian population (five-ten per cent), and therefore was not seen as a threat by the Bolsheviks. Moreover, after 
centuries of oppression the Old Believers were accustomed to behaving inconspicuously and reacting flexibly to measures directed against them. However, one needs only to look at pictures of their centres at the Rogozhsky and Preobrazhensky cemeteries today and compare them with pre-1918 pictures $^{7}$ to see that the anti-religious vandalism unleashed by the revolution did not spare the Old Believers. ${ }^{8}$.

Very little is known about the present-day situation of Old Believers of any grouping. It is gradually becoming possible to draw inferences from obituaries, which have recently begun to provide a-little more information about the dark years of religious persecution.

One significant event in the Soviet period for the Old Believers was the establishment of a second Old Believer hierarchy in 1923 and 1929 respectively in Saratov. As mentioned earlier, a small number of Old Believers loyal to the priesthood expressed considerable doubts about the canonicity of the Belaya Krinitsa hierarchy (founded in 1846-47), rejected its authority and continued to make do with 'runaway' priests or provisional church leaders. In 1923 Archbishop Nikola (Pozdnev) of Saratov and Petrovsk joined this group of Old Believers. At this juncture he actually belonged to the Renovationist movement whose bishops were suspended by Patriarch Tikhon shortly thereafter. For this reason his status is equally questionable from a canonical point of view. In contrast to Ambrosios, however, Archbishop Nikola refused to consecrate bishops, until in 1929 he was joined by another bishop, Stefan (Rastorguyev) of Sverdlovsk, from the Moscow Patriarchate. This made possible the canonical consecration of bishops and thus the continuation of the hierarchy. Although Archbishop Nikola assumed the title 'Archbishop of Moscow and All Russia', the bishop's see was transferred to Kuibyshev in 1955 and to Novozybkov (near Bryansk on the border with Belorussia) in 1963. The leading bishop of the 'Arrchbishopric of Old Orthodox Old Rite Christians' now bears the title 'Archbishop of Novozybkov, Moscow and All Russia'. The double transfer of the bishop's see was probably due to the fact that it seemed appropriate to install the bishop where most of his followers were known to be. This Old Believer denomination is nowhere near as significant as the Belaya Krinitsa jurisdiction, which was known in the Soviet Union as the 'Old Rite Archbishopric of Moscow and All Russia' and which since, 1988 ' has called itself 'The Old Rite Metropolitanate of Moscow and All Russia'. There has so far been practically no rapprochement between the two hierarchies and their church organisations, and with the best will in the world it is not possible to speak of even a tentative alliance.

${ }^{7}$ Moskva zlatoglavaya (Moscow, 1979; Paris, 1980), p. 145 and p. 152.

${ }^{8}$ Cf. Hauptmann, op. cit., p. 75. 
In recent decades the incalculable splintering among the priestless Old Believer denominations has clearly abated. The extreme groups are dissolving, and increasing numbers gravitate towards the more moderate groups, in particular to the Pomortsy, who now probably constitute more than three quarters of all priestless Old Believers. Any rapprochement between the latter and Old Believers who remain loyal to the priesthood is even less to be expected than between the two hierarchies of those who remain loyal to the priesthood.

At the 1971 Local Council, when Patriarch Pimen was elected head of the Russian Orthodox Church, the church's anathemas against the Old Believers (proclaimed in 1656 and 1667) were lifted. Interestingly, Metropolitan Nikodim (Rotov, who died in 1978) held the preliminary talks - at least those that have become known - with representatives of the priestless Old Believer movement, which could indicate more flexible attitudes on the part of the priestless Old Believers, or totally inflexible attitudes among those loyal to the priesthood. It is also possible that Nikodim, then Metropolitan of Leningrad, had talks with the priestless Old Believers simply because they had their centres in his metropolitanate, in the Baltic republics. So far one is left with the impression that the Russian Orthodox Church would very much like to see a rapprochement, but that the Old Believers are biding their time and watching developments, without being particularly active.

\section{The Russian Orthodox Old Rite Church (Belaya Krinitsa Hierarchy)}

The 'Russian Orthodox Old Rite Church' like the 'Christian Church of the Old Rite in Romania', sprang from Metropolitan Ambrosios' conversion to the Old Believer movement (1847) and his consecration of bishops. In Romania Old Believers - nearly all of whom are of Russian origin - are for some unknown reason called 'Lipoveni'.9 The Romanian Old Believers Church consists of some 40,000 members with about 50 congregations, 40 priests and ten deacons. ${ }^{10}$ There is only one diocese, headed by a metropolitan (with his see in Brăila) who has the assistance of two titular bishops (thus when one dies, there are still two bishops who can consecrate a third). In Slava Rusa there is a convent (with more than $\mathbf{3 0}$ nuns) and a monastery (with more than ten monks). Quarterly courses to train priests are also held here. Relations with the sister church in the USSR are not

\footnotetext{
'Hauptmann attempts an explanation in 'Das russische Altgläubigentum', p. 88.

${ }^{10}$ Earl Pope, in a lecture given at the World Congress of Soviet and Eastern European studies, held in 1980 in Garmisch-Partenkirchen.
} 
particularly close because of the political circumstances. There are also some Old Believer congregations in Bulgaria which belong to the Romanian diocese. ${ }^{11}$

The first bishop to head the Old Believers in Russia, Antoni (Shutov), was consecrated in 1853. But he had not been the first bishop of Russian origin in the Belaya Krinitsa hierarchy: a bishop Onufri was consecrated on 3 January 1849 to watch over the congregations in Russia, and in September 1850 he was joined by Bishop Arkadi. To date, nine Old Believer 'Archbishops of Moscow and All Russia' have succeeded him. Since the Millennial 'Council of the church (18-25 July 1988) the head of this church now bears the title 'Metropolitan of Moscow and All Russia', and the church itself has changed its name from 'Old-Rite Archbishopric of Moscow and All Russia' to 'Russian Orthodox Old-Rite Church'. At present Metropolitan Alimpi (Gusev, born in 1929) of Moscow and All Russia rules over the following dioceses: Don and Caucasus (currently vacant); Klintsy and Novozybkov (currently vacant); Kiev, Vinnitsa and Odessa (Bishop Yevtikhi); and Kishinev and Moldavia (Bishop Timon). The boundaries of these dioceses often change, and not every bishop's see is always filled. As in Romania, the church in the Soviet Union is careful always to have at least three bishops to ensure the succession, so that when one dies there are still two more who can consecrate another bishop. The consecration itself is not the only problem involved in appointing a successor to a bishop - more to the point is the question: who can be consecrated as a bishop? As is well known, the Orthodox episcopacy is recruited from amongst the monks. But neither of the two Old Believer Churches in the USSR that retain a priesthood have any monasteries. The last monastery of the Moscow hierarchy of the Old Believers (Belaya Krinitsa), for instance, was closed in the early sixties by state authorities. But it is probably nơt state harassment alone which is responsible for the lack of monks - there seems to be a lack of candidates for monastic life in general. It remains to be seen, however, how things will develop in the current climate of greater religious freedom.

Most Old Believer priests, like Orthodox priests in general, are married, so cannot be considered for the bishop's office. To date, therefore, the succession has been arranged as follows: one has to 'wait' until a priest is wid'owed; then he takes his monastic vows, is consecrated a monk, and after some interim steps is finally consecrated a bishop. Inevitably this is deemed inadequate by many and the Old Believers are seeking to establish a regular monastic life. A practicable and inexpensive solution might be opening up for the "Klaus Steinke, 'Die Altgläubigen in Bulgarien', Kirche im Osten, No. XXXI (1988), pp. 68-87. 
Belaya Krinitsa hierarchy, that is, the Russian Orthodox Old-Rite Church (Metropolitanate of Moscow and All Russia). In Belaya Krinitsa, which has been on Soviet territory since the annexation of Romanian North Bukovina by the Soviet Union during the Second World War, there are the buildings of what used to be an Old Believer convent, as well as other churches and memorials which serve as reminders of the establishment of the first Old Believer hierarchy. Some of the churches are under the control of the Old Believer metropolitanate, but other buildings, probably including the convent, are used by the state. Some of the latter are now being restored to serve as museums. The Old Believers are seeking to take over the restoration work and eventually the management and maintenance of the museum. The church is also hoping to found a small monastic community here in Belaya Krinitsa to take on this work and what is more to be paid by the state for their services in the museum - and so the question of finance would not-present itself as too great an obstacle. Bishops could then be consecrated from this monastic community whenever necessary.

The number of churches was estimated to be over 300 in $1965,{ }^{12}$ but it is probably closer to $100 .{ }^{13}$ There are thought to be at least 50 priests and deacons. ${ }^{14}$ But as long as it is almost impossible to get official data these numbers can serve only as hints. The metropolitan has his see at the Moscow Rogozhsky Cemetery, but does not have at his disposal all institutions previously used by the Old Believers. The Cathedral of the Protecting Veil (Pokrovski sobor) - with places for 10,000 people making it the largest church in the whole of Moscow is the spiritual centre of this Old Believer denomination; the Church of St Nicholas in the Rogozhsky Cemetery, however, is used mainly by the Russian Orthodox Church which owns the central, large sanctuary. On the right is a smaller sanctuary for the Yedinovertsy. On the left side the Novozybkov Old Believers have a tiny chapel for some hundred worshippers, but the chapel does not seem to be frequented very much. The former Cathedral of the Nativity of Mary has been appropriated by the state and was used first as a factory, then a restaurant, and now as a store for 'old government tables, chairs and empty boxes'. ${ }^{15}$

The Russian Orthodox Old Rite Church still seems to be strongest in the Moscow vicinity - thus in the Moscow region alone there are 11 parishes with approximately 50,000 members. The bishops' sees are indicative of its further spread. Priests are trained on the job as there ${ }^{12}$ Michael Bourdeaux, Opium of the People. The Christian Religion in the USSR (London, 1965), p. 175.

${ }^{13}$ Hauptmann, op. cit., p. 127.

${ }^{14}$ Ibid., p. 126.

${ }^{15}$ Sowjetunion heute, 1988 No. 12, p. 35. 
is no seminary offering theological training. Apart from occasional one-off publications, the metropolitanate has at its disposal only the Old Rite Church Calendar (Staroobryadcheski Tserkovny kalendar') with a print run of 7,000 copies. However, this does occasionally include particularly informative articles.

Like any other religious body in the Soviet Union, the Old Believers have been expected to support the foreign policy goals of the state. If the Moscow Patriarchate has seemed at times slavishly patriotic, this can be explained easily by a history of caesaropapism, going back to Byzantine roots. And yet, the Old Believers have also been more than willing to echo Kremlin pronouncements when asked.

If the Orthodox had a deep devotion to the tsar, the Old Believers were deeply devoted to the soil of Holy Mother Russia. Both wings of the Old Believer family have traditional attitudes which make support of communist peace offensives natural to them. In the case of the Belaya Krinitsa church, there is a deep and romantic nationalism, grounded in a desire to live in a pre-schism, 17th-century Russia. ${ }^{16}$ To the Bezpopovtsy, on the other hand, with their identification of the tsar with the Antichrist, support of the peace initiatives of an anti-tsarist regime is an act of piety.

Old Believer support for the Soviet peace campaign first surfaces at 'The Conference in Defence of Peace of all Churches and Religious Associations in the USSR', held at Zagorsk on 9-12 May 1952. An attempt was made to have all legal churches represented - from the Orthodox to the Molokans. First of the Old Believers to appear was the new Belaya Krinitsa archbishop, Flavian (Slesarev), supported by Bishop Iosif (Moryakov) and Archpriest Vasili Korolev (of Rogozhskoye). ${ }^{17} \mathrm{He}$ was followed by the Novozybkov Old Orthodox Archbishop of Moscow and All Russia, Ioan, supported by his Rogozhskoye archpriest, Leonti Dorofeyev. The Conference Report then lists a number of Bezpopovtsy, representing the Pomortsy, the Grebenshchiki of Riga, and the Court of Vilnius. ${ }^{18}$ Eight pages are devoted to a denunciation by Flavian of American germ warfare. ${ }^{19}$ The speeches of Maksim Sergeyev (Pomortsy) ${ }^{20}$ and Leonti Dorofeyev (speaking for Archbishop Ioan) ${ }^{21}$ are given less coverage and are less extreme.

Following the 1952 Peace Conference, the Popovtsy roles appeared to reverse. Belaya Krinitsa tended to be absent or to be represented by

${ }^{16}$ Walter Kolarz, Religion in the Soviet Union (London, 1961), p. 136.

${ }^{17}$ Conférence de toutes les Églises et Associations religieuses de l'URSS pour la défense de la paix dans le monde (Moscow, 1952), p. 11.

${ }^{18}$ Ibid., p. 12.

${ }^{19}$ Ibid., pp. 101-108.

${ }^{20}$ Ibid., pp. 147-51.

${ }^{21}$ Ibid., pp. 174-78. 
a lesser cleric, while Novozybkov always sent a senior hierarch. ${ }^{22}$ Novozybkov has usually allied itself with the stands taken by the patriarchate, whilst the Belaya Krinitsa spokesmen have appeared less willing. The Bezpopovtsy have continued to send their most senior men who have enthusiastically endorsed all Soviet peace initiatives.

Willingness to adapt flexibly to Soviet reality, in supporting the peace activities of the Communist Party, once more demonstrates the survival tactics of the Old Believer movement. If they can maintain their religious beliefs, they are willing to be pragmatic about virtually anything else.

In 1984 in Brăila (Romania), a bishop - the monk-priest Iosif (Basargin) - was consecrated for the first time for Australia, the USA and countries other than the Soviet Union and Romania. Thus in addition to its Russian and Romanian branches, the Old Believer Church founded in Belaya Krinitsa in 1847 has now acquired a strong branch in diaspora. The bishop's see is in Lidcombe, just west of Sydney, Australia. Various waves of emigrants converged on Australia, the most significant probably coming after the declaration of the People's Republic of China in 1949; many others came to Australia from South America, where they found the climate too overpowering. The North American Old Believer diaspora has well over 100 year's tradition. The decision to establish the bishop's see in Australia is due to the fact that the Old Believers of Oregon, Alaska, and Canada are less well-disposed to Belaya Krinitsa jurisdiction. Most of them - migrants from China (Harbin, Sintsyan) and from Turkey are Beglopopovtsy or priestless Old Believers. The wealthiest Old Believer communities are currently scattered throughout South America, but agricultural success is achieved at so much expense to health that the level of migration is very high.

\section{The Old Orthodox Archbishopric of Novozybkov, Moscow and All Russia}

In 1923 the Renovators' Archbishop Nikolai (Pozdnev) converted to the Old Believer movement and was won over by congregations loyal to the priesthood. When Bishop Stefan (Rastorguyev) left the patriarchal church and joined Bishop Nikolai in 1929, the succession of bishops was assured according to the canon. Although it had only just been formed, the young church was able to survive the $1930 \mathrm{~s}-$ years which under Stalin saw the destruction of all institutional church life - possibly because it was such a relatively insignificant denomination. The present leader of the church, Archbishop Gennadi ${ }^{22}$ See Journal of the Moscow Patriarchate, 1971 No. 6, p. 18. 
(Antonov, born 1903) of Novozybkov, Moscow and All Russia, governs the dioceses of Perm and Kuibyshev as well as a very small congregation in Moscow which has at its disposal the northern section of the Church of St Nicholas at the Rogozhsky Cemetery.

The bishops' sees are an indicator of the main distribution of the Novozybkov denomination - the middle Volga (Kuibyshev), the Kama region (Perm') and the south-west regions of the Russian Republic where Novozybkov and Klintsy lie between Bryansk and Gomel' (Belorussia); there are also churches in Siberia, the most important of which would appear to be the church in Orenburg. The work of the aged archbishop is distinguished by an intensive programme of visitation which takes him to all the areas where he has churches.

The archbishopric has only $15-20$ congregations ${ }^{23}$ with at most 20 priests. The archbishop is supported by three bishops, namely (in 1989) Flavian (Vdovin) of Moscow, Grigori (Kornilov) of Kuibyshev, and Leonti (Krekhetov) of Perm'. The episcopacy might appear to be excessively large in comparison to the small number of priests, but here too the canonical safe-guarding of the episcopal succession is a determining factor for the number of bishops. As in the Old Believer Church of Belaya Krinitsa, there is no training for the priesthood as far as we know - priests are trained by years of altar service. The Old Orthodox Old-Rite Church Calendar, (Drevnepravoslavny Staroobryadcheski Tserkoviny kalendar'), known since 1987 as the Old Orthodox Calendar (Drevnepravoslavny kalendar') which has a print run of 3,000 copies, reports on church life once a year, and attempts at the same time to meet catechismal needs.

This small church now appears to be caught in a real struggle for survival, but it continues to observe the 'old faith' more strictly than the Belaya Krinitsa Church. ${ }^{24}$ There does not appear to be any likelihood of a rapprochement between the two Old Believer hierarchies of Moscow and of Novozybkov in the foreseeable future. Their attitude towards each other is characterised by hostility rather than by any friendly cooperation or ecumenical disposition.

\section{The Position of the Priestless Denominations}

Little is known about the life of the priestless communities. Many small groups formed larger ones, extreme groups dissolved, and the

\footnotetext{
${ }^{23}$ Peter Hauptmann says 16 in 'Aus der russischen Altgläubigentum', Kirche im Osten No. XXXI (1988), p. 130.

${ }^{24}$ Peter Hauptmann, 'Das russische Altgläubigentum 300 Janre nach dem Tode des Protopopen Avvakum' in Kirche im Osten No. XXIX (1986), p. 105.
} 
general secularisation of society also claimed its victims from among the Old Believers. Hierarchical structures are in themselves alien to priestless believers as a matter of principle. Despite this, in the Baltic republics which were independent between the wars, that is in the former places of refuge which to this day form the most important centres for priestless believers, a relatively rigid organisational structure has developed.

Nowadays it is not really possible to see the Pomortsy and Fedoseyevtsy as rival Old Believer groups, but rather as variations of one particular form of beliefs. They enjoy prayer fellowship together and recognise each other's baptism (this is not the case with other priestless groups, for anyone converting to them has to be re-baptised). And recently the Pomortsy and Fedoseyevtsy have combined to publish a church calendar for priestless believers. Finally, with the 1982 election of the late M. I. Chuvanov as President of the Moscow Fedoseyevtsy church at the Preobrazhensky Cemetery, the organisational inclusion of the Fedoseyevtsy in the 'Supreme Old-Rite Council in the Lithuanian SSR' was begun.

Until 1989 there were still no training facilities for Old Believers, apart from the provisional preparatory training available for church leaders in Riga (Grebenshchikov congregation). In the 1985 calendar for priestless Old Believers, it was pointed out that:

The preparation of church leaders is carried out individually because the 'Old-Rite Church of the Pomore' does not at present have any special training facilities. Training tends to be concentrated in the larger churches where there are qualified and well trained spiritual leaders.

However, glasnost' has brought positive changes for the priestless Old Believers: on 1 October 1989 permission was granted for the establishment of a theological college, the first theological institution for the Old Believers since 1930. Attempts seem at last to be underway to bring closer together the priestless Old Believers: the Pomortsy decided at a conference on 21 November 1989 to have one united spiritual centre.

\section{The Baltic Churches}

'The Supreme Old-Rite Council in the Lithuanian SSR'is the oldest union of priestless Old Believers. It is supported by the the 'Spiritual Commission of the Old-Rite Church of Pomore' whose task it is to clarify questions of theology and church canons in particular. A 'Central Council of Old-Rite Believers in Lithuania' had already been 
established in 1922, which was matched in 1925 by the 'Old-Rite Eastern Church without a Spiritual Hierarchy' established in what was then Polish Wilna (Vilnius). This Central Council has been used by the state since Stalin's time as an instrument of control over the priestless Old Believers' congregations in Lithuania. ${ }^{25}$ The congregations have only a loose link with the state-controlled central organisation. Church life tends to be centred instead around the large congregations who have a rich tradition, serving as an example and determining the spiritual life of their locality.

The Supreme Old-Rite Council in Lithuania embraces a total of 50 congregations, of which the 7,000-member parish in Vilnius is the most important. However, half of these congregations are clearly very small. The centre in Vilnius also includes the leadership of this group. After Vilnius in size and importance comes Kaunas. In the years between the wars seminary courses were held in this church to train church leaders; there were also seminary courses in the Vilnius Old Believers' centre which was on Polish territory at that time. After the annexation of Lithuania by the Soviet Union such courses were no longer possible. The church in Memel (Klaipeda) likewise has over 1,000 members. The number of priestless Old Believers in Lithuania probably exceeds $50,000,{ }^{26}$ all ethnic Russians.

In 1974 a 'Council of the Old Rite Church of Christ of Pomore' was held in Vilnius, which was attended by 116 church leaders and a further 400 lay representatives of all the Pomortsy churches in the whole Soviet Union - an unusual show of strength and a rare chance to deal with outstanding questions of theology and church canons within a larger framework. There are thought to be about 30 church leaders in Lithuania. It has recently been learned that in some churches the service is occasionally taken by women, who have a firm place in the lower ranks of the clergy as rubricists (ustavshchiki) and choir leaders but not among the present spiritual leadership which contsists of 'church leaders' (nastavniki, nastoyateli). Another council was convened in connection with the millennium of the baptism of Rus', but so far little is known about this.

Any publishing activity has so far been limited by state-imposed restrictions. The Old-Rite Church Calendar (Staroobryadchesky Tserkovny kalendar') with its 112 pages is far more than just a calendar, and serves above, all as a vehicle for spiritual instruction. There has recently been a certain amount of co-operation between the Moscow Patriarchate and the Supreme Council, and the patriarchate's publishing house has reprinted various liturgical books for the

\footnotetext{
${ }^{25}$ Nastavnik Ioan Mirolyubov (Riga), President of the Central Council of the Old-Rite Church of the Pomore in Latvia, in a letter to the author, 27 May 1989.

${ }^{26}$ Peter Hauptmann, Kirche im Osten, No. XXX (1987), p. 143.
} 
Old Believers. There are high hopes of being allowed to publish a comprehensive yearbook, but to date an expansion of the calendar has had to suffice. In connection with the millennium, the publishing house of the Moscow Patriarchate printed the Prayer Book (molitvennik) of the Old-Rite Church of the Pomore' for the Supreme Old-Rite Council in Lithuania. In 1990 publication is to begin of a quarterly Grad Kitesh (The Town of Kitesh) ${ }^{27}$ which will have a print-run of between 5,000 and 7,000 copies.

The 'Grebenshchikov' church in Riga, in existence since 1760, recognised the spiritual authority of the priestless Old Believers' centre in Vilnius. This church also appears as joint publisher of the above-mentioned Old-Rite Church Calendar, which is, in fact, published in Riga. With about 10,000 members the congregation in Riga is the most important of the 64 parishes (there were 100 in 1952) of priestless Old Believers in Latvia. In the Riga area alone live 25,000 Old Believers of this denomination. Since there is no clear-cut association, congregations orientate themselves by the Riga church. For a long time all attempts by the Latvian churches to establish a national organisation failed, and so this loose structure has remained. On the other hand, there was a degree of practical subordination to the Supreme Old-Rite Council in Lithuania, evidence of which was the membership of a representative of the Riga Grebenshchikov church on the 12-man Spiritual Commission of the Old-Rite Church of the Pomore in Vilnius. Only in February of 1989 was a Central Council of the Old-Rite Church of the Pomore in Latvia established. Now it is an open question whether Riga will further recognise the spiritual leadership of Vilnius. Courses to train church leaders used to be held sporadically in the Grebenshchikov church, but on 1 October 1989, the Central Council in Riga received permission to establish a theological college (dukhovnoye uchilishche). This will be the first theological institution for Old Believers of any denomination in the Soviet Union sihce the 1930s. Initially the institute will run two-year courses but it is planned to turn it into a seminary with four-year courses. Fourteen students are enrolled for the first year and a library is in the pipeline. In 1990 the Riga Central Council of Pomore Old Believers is to produce a quarterly journal Zlatostroi (Stream of Gold) with a print-run of 10,000 copies. The Central Council is at present preparing a book of photographs about the life of Old Believers in Latvia. ${ }^{28}$

\footnotetext{
${ }^{27}$ According to legend Grad Kitesh existed as a Russian town until the 13th-century Mongol invasion. The Lord would not allow the city to be destroyed by the heathens, so he made it disappear as the Mongols approached. Grad Kitesh is reputed still to exist, hidden from sight by the waters of Lake Svetloyar in the Gorky region. For further details see Walter Kolarz, Religion in the Soviet Union (London, 1961), pp. 138-39.

${ }^{28}$ Nastavnik Ioan Mirolyubov, President of the Central Council of the Old-Rite Church of the Pomore in Latvia, in a letter to the author, 19 November 1989.
} 
Just as attempts by the priestless Old Believers in Latvia to establish an organisational union failed for a long time, the same has been true in Estonia which has 12 priestless Old Believer congregations. A church leader from Tallinn belongs to the 12-man Spiritual Commission of the Old-Rite Church of the Pomore, so the priestless Old Believers in Estonia are represented here. At present no statistical details on the Estonian parishes are available.

\section{The Moscow and Leningrad Churches}

The Pomortsy form the majority of priestless Old Believers, except in Moscow, where the Fedoseyevtsy dominate. There are no statistics available for the size of the Moscow Old-Rite Church of the Pomore, as it is officially called. The statement that in 1836 the church consisted of some 10,000 members ${ }^{29}$ gives no indication of present circumstances. Its church building was closed after the revolution, though in 1930 it was allocated the eastern part of St Nicholas' Church at the Preobrazhensky Cemetery (the centre of the marriage-less Fedoseyevtsy movement). To this day, it is the only building available to this continually growing Moscow Pomortsy church which doubtless still numbers many thousands.

Like the Riga church or the Lithuanian Council, the Fedoseyevtsy church located at the Preobrazhensky Cemetery is not a single church but the spiritual centre of the priestless, marriage-less Fedoseyevtsy churches extending far beyond the Moscow region. In the Moscow region alone, there are thought to be still some 10,000 adherents. There is no organisation, hierarchy or leadership structure among their congregations.

There was a spiritual school at the Preobrazhensky Cemetery dating from the late 18th century, which was able to continue for a short while after the revolution. The Soviet authorities allowed an Old Believer People's Academy to open (Staroobryadcheskaya narodnaya akademiya) but it was soon closed - probably in the mid-1920s.

For decades the leader of the Moscow Fedoseyevtsy church was Mikhail Ivanovich Chuvanov, who died in 1988 at the age of 98 . His influence extended far beyond the Old Believer milieu: there have been reports about him in the Journal of the Moscow Patriarchate on his birthdays, and the secular press has also honoured him as a great collector of old icons and church books, as an authority on pneumatic singing (Znamennoye peniye) and old Russian church literature, and as a promoter and publisher of the works of talented Soviet authors.

${ }^{29}$ Hauptmann, op. cit., p. 118. 
There is an Old-Rite Pomore church in Leningrad too. This was clearly an active congregation until the beginning of the 1930s when the church was closed down. It took: a long time to recover from the losses suffered as a result of Stalin's liquidations and Khrushchev's persecutions. Since the late 1970s church life - now in a small prayer house - appears to have been consolidated, but not more is known about the size of the church or of other churches in its vicinity. In 1989 the former church of the Pomortsy near the centre of Leningrad was handed over to the Evangelical Christians-Baptists.

\section{The Polish Churches}

In 1928 the Old-Rite Eastern Church without a Hierarchy (Wschodni Kościol Staroobrzedowy nie posiadajacy hierarchii duchownej) and its leadership, the Supreme Old-Rite Council in Lithuania, was recognised by the state. After the crushing of Poland by Hitler's Germany, Vilnius (following the pact between Hitler and Stalin) was handed over to Lithuania, and so the Old Believer Church in Poland lost its most important centre. Admittedly the incorporation of formerly German East Prussia brought Poland several Old Believer settlements, but for a long time these had been seriously weakened by assimilation into the German environment on the one hand and by conversion to Yedinoveriye on the other. Since 1945, the assimilation of the Russian Old Believers into the Polish environment has continued apace. There are thought to be only some 2,000 members now in the four Old Believer congregations in Poland (GabovyGrondy, Suwalki, Wodzilki and Wojnowo). In the Wojnowo area, there are probably less than 100 practising Old Believers, with another 50 or fewer belonging to the Yedinoveriye group. Migration and sęcularisation are further factors accelerating the demise of these Old Believer congregations which in the 19th century had over $1 ; 000$ members. Church services are hardly ever held. An Old Believer convent in Wojnowo will be handed over to private ownership after the death of the last two sisters who are not really nuns at all. ${ }^{30}$

In 1984 a council of priestless Old Believers of the 'Old-Rite Church of the Pomore in Poland' was held in the Suwalki district, attended by 50 delegates. Apart from administrative decisions, the wish was expressed to maintain close spiritual links with fellow-believers in the USSR, above all with those in Lithuania. ${ }^{31}$

${ }^{30} \mathrm{Cf}$. E. Iwaniec, Iz dziejów starobrzedowców na Ziemiach Polskich 17-20w, (Warsaw, 1977), pp. 79-112; Gerd Stricker, 'Russisches Altgläubigentum im Deutschen Reich Philipponen in Ostpreussen', in Konfession, Gesellschaft, Staat. Religiöse Gruppen im Osten des Deutschen Reiches, edited by Hans Hecker and Silke Spieler (Bonn, 1990).

${ }^{31}$ Hauptmann, op. cit., p. 146. 


\section{Yedinovertsy}

The Yedinoveriye 'union' existing since 1800 between the Russian Orthodox Church and the Old Believers did not prove successful. The Old Believers were denied their own bishop and everything else was calculated to merge them into the Orthodox Church. In the Soviet Union the end of this merger process is foreseeable, although this Old Believer group within the Patriarchal Church still has the use of one part of St Nicholas' Church at the Rogozhsky Cemetery.

In America, doubtless because of the ethnically varied diaspora, there is a noticeable movement of Old Believers towards the Russian Orthodox Church in Exile. This church totally rejects the Moscow Patriarchate viewing it as a puppet of the Soviet state and therefore not inwardly free. Surprisingly, it was the oldest priestless Old Believer church which in 1983 subordinated itself to the Russian Orthodox Church in Exile and allowed its leaders to be ordained, doubtless aware that in view of the conditions prevalent in North America and of present-day circumstances, it would be impossible for this ethnic and religious mini-minority to survive on its own. At its 1974 Council, the Russian Orthodox Church in Exile lifted the anathemas proclaimed against Old Believers in 1656 and 1667, thereby creating the prerequisite for Old Believer churches to be accepted into the Church in Exile while retaining their own rites.

\section{Prospects}

The Russian Old Believer movement worldwide finds itself in what may be seen as a situation of radical change. The divisions between the priestless Old Believers are disappearing, the Pomortsy (who recognise marriage) form the largest group of all priestless Old Believers and are alsb attracting the second-largest group, the Fedoseyevtsy, who reject marriage. At the same time it is clear that even though they are a minority, the priestless Old-Rite Churches are intellectually more active despite their loose structures, than the Old Believer Churches with a priesthood. It may seem paradoxical at first, but is perhaps symptomatic, that the Moscow Patriarchate's efforts since the 1971 Council, when the anathemas imposed in the 17th century were lifted, have been first and foremost directed towards the priestless Old Believer churches. Both the Old Believer hierarchies appear - as far as can be judged from outside - to be less established inwardly, to be particularly hampered in their spiritual development by the lack of any well-ordered training for the priesthood, and also to face great difficulties ensuring the continuation of the hierarchies (particularly in 
the small Old Believer Archbishopric of Novozybkov). Like other churches or perhaps even more than other churches in the Soviet Union, the Old Believer denominations allowed themselves to be drawn into Soviet peace propaganda, and extensive declarations following the party line have appeared in their few publications. It remains to be seen to what extent the perestroika of Soviet religious policy will affect them.

\section{Bibliography}

V. V. Andreyev, Raskol i ego znacheniye v narodnoy russkoy istori. St Petersburg, 1870.

Bukhtarminskiye Staroóbryadtsy. Leningrad: Soviet Academy of Sciences, 1930.

Iohannes Chrysostomus, 'Die radikalen Sekten der russischen Altgläubigen', in Ostkirchliche Studien No. 21 (1972), pp. 3-29, 105-115; 'Das Problem der Ehe bei den russischen Altgläuben', in Ostkirchliche Studien No. 20 (1971), pp. 130-58; 'Die "Pomorskiye otvety" als Denkmal der Anschauungen der russischen Altgläubigen gegen Ende des ersten Viertels des 18. Jahrhunderts' in Orientalia Christiana Analecta Vol. 148. Rome, 1957.

Robert O. Crummey, The Old Believers and the World of Antichrist: The Vyg Communities and the Russian State 1694-1855. London, 1970.

V. G. Druzhinin, Raskol na Donu v kontse 17.ogo v. St Petersburg, 1889.

N. K. Gudzij, Zhitiye protopopa Avvakuma, im samim napisannoye, i drugiye ego sochineniya. Moscow, 1934.

Peter Hauptmann, Altrussischer Glaube. Der Kampf des Protopopen Avvakum gegen die Kirchenreformen des 17. Jahrhunderts. Göttingen, 1963.

Nicholas Lupinin, Religious Revolt in the 17th century: The Schism of the Russian Church. Princeton, 1984.

V. I. Milovidov, Staroobryadchestvo v proshlom i nastoyashchem. Moscow, 1969; Sovremennoye staroobryadchestvo. Moscow, 1979.

Baldur Panzer (Editor),' Sprache, Literatur und Geschichte der Altgläubigen. Heidelberg, 1988.

Viktoria Pleyer, Das russische Altgläubigentum. Geschichte, Darstellung in der Literatur. Munich, 1961.

N. N. Pokrovsky, Antifeodal'ny protest uralo-sibirskikh krest'yanstaroobryadtsev $v$ 18om $v$. Novosibirsk, 1974. 
A. S. Prugavin, Staroobrydchestvo vo vtoroy polovine $19 v$. Moscow, 1904.

D. Scheffel, 'The Russian Old-Believers of Alberta', Canadian Geographic, October-November 1983, pp. 62-69.

P. S. Smirnov, Istoriya russkogo raskola staroobryadstva. Ryazan', 1893.

Gerd Stricker, 'Russisches Altgläubigentum im Deutschen Reich Philipponen in Ostpreussen', in Konfession, Gesellschaft, Staat. Religiöse Gruppen im Osten des Deutschen Reiches, edited by Hans Hecker and Silke Spieler. Bonn, 1990.

I. Syrtsov, Vozmushcheniye solovetskikh monakhov-staroobryadtsev v 17 om v. Kostroma, 1888.

George Vernadsky, The Tsardom of Moscow (5 vols.), Vol. 5. New Haven - London, 1949.

S. Zenkovsky, Russkoye Staroobryadchestvo. Dukhovniye dvizheniya I7ogo v. Munich, 1970. 